\title{
Fear of Crime in Urban Settings: Influence of Environmental Features, Presence of People and Social Variables
}

\author{
Rangajeewa Ratnayake \\ La Trobe University, Australia \\ R.Ratnayake@latrobe.edu.au
}

\begin{abstract}
Past researches have shown that fear of crime is influenced by environmental features and social variables. Most such studies on fear of crime have paid attention to either environmental clues or social-cultural variables independently. Primarily this paper argues that planners and planning practice require a holistic understanding of fear of crime to be effective at policy development, implementation and evaluation. A more holistic understanding of fear of crime can be achieved by combining environmental approaches and social approaches. One conceptual framework that can help to achieve this is prospect and refuge. Prospect and refuge, as a theoretical framework, enables researchers and planners to consider how environmental features such as the density of the urban fabric, lighting, and social features such as presence of people and activity jointly influence fear of crime in relation to subjective experience of individuals' identifiable characteristics which for this paper, comprise gender and status as a local or international Asian student.
\end{abstract}

\section{Introduction}

Fear of crime is a vital concept to be studied because it affects the well-being of individuals and society as a whole. Fear of crime can have detrimental effects on individuals' psychology as it can limit people's freedom and choice, significantly influencing individual behaviour in space. Perception of crime restricts individual mobility; it impacts on individuals' health and well-being, hinders outdoor participation, leisure activities, and contributes to dissatisfaction with public spaces, neighbourhood and overall life (Blobaum \& Hunecke, 1998). At the societal level, the fear of crime burden may be unfairly placed on those already socially and economically disadvantaged as they may not have sufficient resources to protect themselves or to move from high crime areas (Jackson, Farrall, \& Emily, 2007). The intention of this paper is to explore theoretical models that explain the relationship between exterior site characteristics and feelings of fear in relation to crime. This paper argues that planners and planning practice will be more effective at policy development, implementation and evaluation if evolutionary biology (prospect \& refuge theory) and socio-cultural theory are merged with current planning and urban design theory. The merging of these theoretical and conceptual models will create a more holistic understanding of fear of crime based on the dynamic relationship between people and their environments.

\section{Towards a Working Definition for Fear of Crime}

Many studies adopted Ferraro's (1995, p.4) definition of fear of crime. His definition is: 'Fear of crime is an emotional response of dread or anxiety to crime or symbols that a person associates with crime'. This paper also adopts a similar definition in its examination fear of crime in the built environment. Ferraro's definition is useful because it treats fear of crime as a psychological condition resulting from physical signs as well as the various meanings individuals have based on their differing socio-cultural characteristics. Thus, for the purpose of this study, the paper adopts a working definition that fear of crime is situational in that individuals' fear of crime can be understood as being afraid, anxious, or concerned about becoming the victim of a crime in public areas in relation to immediate environmental clues (Gabriel \& Greve, 2003). 
Crimes in this sense can include physical assaults, threats, robbery, homicide, as well as crimes not impacting on the person directly such as the theft of a person's resources (such as money). It is believed that all situations ultimately represent a threat to physical wellbeing (Garofalo, 1981). It is also believed that fear could be elicited by events and conditions that have a potential of physical harm and threat (e.g., automobile accidents, uneven pavement edges, ditch on the foot path). Even though such events and conditions have a potential physical harm generally they are not perceived as crimes. It is evident in previous studies on fear of crime that these events or conditions are not viewed as crimes (Garafalo, 1981; Nasar, Fisher, \& Grannis, 1993). Therefore, this paper also does not consider them as crimes.

\section{Significance of Fear of Crime for Planners and Planning Practice}

A crucial influence on whether people will use or avoid urban public spaces is the degree to which they feel safe in them. The actual risk of becoming a victim of crime is usually less than the fear people feel, but it is the latter that can lead to avoidance (Kelly, 1986; Koskela \& Pain, 2000). Ironically, the people who are least at risk (for example, older people) tend to be most fearful, while young men, who are those most at risk, are less fearful (Sundeem, 1984). Many researchers found that the majority of women and elderly did not use some spaces in the city centre at night due to fear of violence. Many young women face sexual harassment in public and this elevates their levels of fear considerably. This undermines the intention of public spaces to be democratic places for all (Shaftoe, 2008; Tulloch et al., 1998) At the same time if people avoid public spaces, particularly at night due to fear of crime, such spaces become less vibrant, visually unattractive and less stimulating for residents and visitors.

In the context of Australian metropolitan and regional cities, international and migrant population has increased dramatically over the last 10 years (Australian Education International, 2009) and the expectations that growth will continue. To ensure this growth, the safety issues of international students and citizens have become increasingly important. From the perspective of local authorities, the more that can be learned about issues of people, the better they can create a conducive living environment and reputation that will attract not only international students but also other people including skilled migrants and tourists.

In recent times, there has been considerable research focusing on safety in Australia. Research findings highlight that feeling of unsafe in public spaces particularly at night is a significant issue for many people in Australia. According to ABS Crime victimization survey in 2008 , over four million adults, or $26 \%$ of those aged 18 years and over, reported feeling unsafe when walking at night alone in their neighbourhoods or taking public transport at night alone (Australian Bureau of Statistics, 2010). It has also been revealed that many international students have felt unsafe in public places in Melbourne metropolitan area (Andrews \& Gatersleben, 2010). While there has been considerable research focusing the crime and general safety issues of international students in metropolitan areas in Australia, fear of crime in public spaces in regional cities has been neglected. At the same time the recent studies have not adequately studied the influence of features of the built environment on fear of crime in urban settings in Australia.

It is the primary responsibility of planners, urban designers, and local authorities to design and manage urban spaces. Decisions such as where public spaces will be located, how parks, open spaces, markets, and bus stations, look, and what features will be included, will be ultimately determined by these actors. Such planning decisions will facilitate create wellintegrated or fragmented urban settings. Integrated spaces within the city centre that incorporate a wide range of day and night time activities is associated with reducing temporal activity gaps and thereby attracting a wide a range of social groups. Mixing of land uses, especially with residential redevelopments in commercial settings is likely to increase pedestrian activities in city centres and thereby increase informal natural surveillance. Furthermore, people are likely to use well-lit and accessible places in public settings. In 
contrast, separation of retail shops and entertainment facilities from bus stops and car parks will create less integrated city centres. This would result in under utilization of some parts of city centre and low level of pedestrian activity across over a longer time-span especially at night-time. Gaining knowledge about how different environment settings and social variables act together to influence people's fear of crime, particularly at night in public space, and the experience of people in these spaces is integral for planners and planning practice in Australia because Australian planning education policy values cultural diversity and multiculturalism (Planning Institute of Australia, 2010).

\section{Fear of Crime in Public Spaces}

Fear of crime in urban public spaces is a complex environmental, political, sociocultural, psychological and physiological phenomenon that is inadequately understood within the planning profession. Planners and the planning profession have primarily addressed matters related to fear of crime through instrumental technical rational approaches. These approaches have transformed outcomes from research and empirical studies such as Newman's defensible space and Jacobs' "eyes on the street" into CPTED guidelines and programs (Jacobs, 1961; Newman, 1972) and practical, useable and enforceable policy such as Safer by Design Guidelines (UN-HABITAT, 1996). However, the development, implementation and enforcement of regulations, programs and supporting education and marketing can be undermined by a superficial understanding of fear of crime as a dynamic relationship between people and their environment.

\section{Theories of Fear of Crime}

Factors of fear of crime have been broadly discussed in relation to two main theoretical perspectives: theories related to environmental design and theories related to socio-cultural variables. Planners and the planning profession has been dominated by matters related to environmental design and changes to the physical environment; these planning approaches have been viewed as too environmentally deterministic (Talen, 1996).
This is some evidence that there is a shift toward more socio-cultural approaches, however these are often focused on the subjective experience of fear of crime. Sociocultural approaches may influence both perspectives on the periphery; however they are not explicitly interrogated or applied within the planning profession. To get beyond objective and subjective explanations of fear of crime in urban spaces, environmental and social approaches need to be combined so planners and the planning profession can achieve a more holistic understanding of the dynamic between people and their environment.

\section{Environmental Approaches}

Regarding the environmental design thesis, some researchers argue that physical characteristics of a setting can affect our perceptions and guide our behaviour in terms of how we use space. Lack of concealment, surveillance, area for refuge, escape routes for individuals and lack of maintenance may provoke fear in the minds of people (Marusic, 2010; Newman, 1972). Perception of crime can also be attributed to physical disorders of the neighbourhood such as deteriorated or abandoned buildings and graffiti.

The relationship between environmental clues and fear of crime has been studied in city planning, urban design and architecture throughout the second half of the twentieth century. Regarding this, Wilson and Kelling (1982) introduced a theory known as 'Broken window theory' which has been used to explain many studies in fear of crime and physical environment (Carmona \& Tiesdell, 2007; Loukaitou-Sideris, 1999; Loukaitou \& Eck, 2007; Wilson \& Kelling, 1982). Broken window theory predicts that if a building has a broken window and is left unrepaired, the other windows will be broken as people think that no one cares (Doran \& Lees, 2005). The key idea of this theory is that if disorderly behaviour is unnoticed, it soon leads to further disorder and at last to serious crimes. Such disorderly places may create a sense fear among residents who may avoid such places.

Physical disorder and fear of crime hypothesis has been tested by many researchers. One 
study done in American neighbourhoods (Skogan, 1990) indeed found a link between fear of crime areas and neighbourhood physical character. Similarly, findings confirmed that neighbourhood lack of cohesion, neighbourhood incivility and relatively high neighbourhood crime level positively correlated with risk of victimization (Borooah \& Carcach, 1997). Other studies have shown relatively less correlation between physical disorder and high levels of crime (Samson \& Raudenbush, 1999), however they still support the notion of disorder and fear of crime hypotheses.

In terms of other studies and approaches on fear of crime and built environment, the Crime Prevention Through Environmental Design (CPTED) approach is important in creating built environments in such a way that fear of crime and opportunistic crime are reduced based on the influence of design. CPTED is also used in environment psychology to design and manage spaces to manipulate human behaviours (Jorgensen, 2007, p. 26). This concept was developed by Ray Jeffery (1971) and is explained as the "proper design and effective use of the built environment that can lead to a reduction in the fear of crime and incidents of crime" (Crowe, 2000, p. 1). This approach is used by planners to manage settings such as buildings, parks, open spaces, and streets to mitigate incidences of crime and fear of crime.

Informing the CPTED approach, there are other environmental design concepts that have been developed by Jacobs" "eyes on streets" (Jacobs, 1961), Newman's "defensible space" (Newman, 1972), and Poyner's "design against crime (Poyner, 1983)" which explain the features of the built environment and their relationship with the perceived safety of individuals. Jacob (1961) argued that modern architectural forms and spatial designs, particularly residential layouts in cities, abandoned the traditional relationship of houses and sidewalks.

These traditional layouts and houses have been replaced with new high-rise buildings which have the ability to break down community cohesiveness and destabilize informal social control. She argued that destabilisation occurred because modern housing and layout designs lack the ability to provide surveillance (eyes on streets) over strangers on the road.

Newman (1972) and Poyner (1983) extended this idea by examining intricacies between housing design and criminal activity. They emphasized that architectural design (buildings heights, windows, staircases) and urban design features (streets, open spaces) could improve community cohesiveness and could create "defensible space" against criminal activity. For example, one way this could be done is by defining individual property through pathways and fencing. The essence of a defensible space program is to restructure the physical layout of communities to allow residents to control areas around their homes. This includes the streets and the grounds outside their buildings, and the lobbies and corridors within them. Newman believed that these environmental designs not only preserve individuals from criminal activity but also people can realize their commonly held values and life styles (Newman, 1996).

However, some argue that town planning (street design, layout planning, building designs, etc.) cannot build a sense of community by deterministically bringing people together (Crenshaw \& John, 1989; Talen, 1996). In other words, they argue that there is no direct relationship between environment and behaviour (feeling of safety and avoidance behaviour), even though town planning may have a catalyst effect. They stress the other non-physical territorial variables in the promotion of sense of community sentiment such as shared values, class, life styles, and length of residence (Gans, 1962; Hunter, 1975). Nevertheless, all the above research supports the notion that town design may provide a setting for social interaction, and social interaction can build a sense of community, which in turn can contribute to feelings of safety (Jacobs, 1961; Talen, 1996).

Hence, work by Jacobs, Newman and Poyner is important in relation to environmental design and criminal activity. They provide insights into social relations in space and the 
need for defined territory that discourages criminal activity by changing the built fabric. Newman's and Jacob's findings assert that people feel and are more confident to behave in urban areas when they are not isolated from contact with the larger urban realm. When people are seen by others, it allows casual surveillance and those bystanders may provide assistance in unsafe situations.

Many urban planning studies have focused on crime hotspots and how to enhance safety through employing urban design principles in the design or redesign of those public spaces (Jeffery, 1971; Poyner, 1983). The term "hotspots" refers to existing high-crime locations that may impact on a nearby development (Maltz, Gordon, \& Friedman, 1990). These can include areas of high car theft such as certain underground parking lots; sites of pick pocketing such as bus terminals; or locations of robberies such as dark enclosed spaces.

In the context of urban design many interventions have been proposed to improve the safety of such settings such as lighting, mixing of land uses, landscaping, and building design (Crowe, 2000). Although this paper primarily focuses on fear of crime, the above ideas are important as they are related to fear of crime literature such as Appleton's theory of prospect and refuge. For example, importance of lighting and hiding spaces in urban settings has been discussed in CPTED approach.

As stressed earlier, the intention of this paper is to investigate feelings of fear in relation to crime. As shown above in this paper, previous studies focused on actual crime locations (hotspots), but this article focuses on "hotspots of fear" and how people experience fear of crime in relation to certain features of the built environment. Such places are not necessarily actual crime locations but those places where individuals' sense of fear restricts their behaviour in public space.

The search for environmental approaches into fear of crime and crime has been perused mainly by humanistic geographers, urban planners, urban designers, and phenomenologists. The essence of their argument is that visual aspect of the environment shapes our preference of landscape. In terms of fear of crime, people evaluate characteristics of sites such as lighting, and physical and social conditions of the sites when they use such places and move through such sites. In other words, people make subjective interpretations based on their social context for visual objects (features of the built environments). In this context, visual landscape or environment features such as buildings, streets, vistas and parks act as signs which convey some meanings for people (Gottdiener, 2010).

In this regard, Appleton's theory of prospect and refuge provides a valuable conceptual framework for understanding of individuals' perception of fear of crime. Due to Appleton's grounding in environmental psychology, it focuses particularly on feeling of fear of crime when walking in the built environment. The next section will discuss Appleton's theory of prospect and refuge and its applicability to fear of crime.

\section{Fear of Crime and Prospect and Refuge Theory}

Appleton's (1975) perspective has developed from a substantially different intellectual background compared to research programs that have been undertaken either to assess the connection between the organisation of the environment and the opportunity for crime or the influence of socio-cultural variables on fear of crime. This theory focuses on two environmental characteristics that are seen as the most important indicators of safety: refuge and prospect. Indeed the ability to see (prospect) without being seen (refuge) is basic to many biological needs. Therefore, this theory focuses on the primitive origins of contemporary environmental perception and preferences.

Prospect-refuge theory was first introduced to explain human environmental preferences. It was believed that the environment that afforded more prospect (open view) and refuge (protection) formed an advantage to humans. According to Appleton's prospect and refuge theory (Petherick, 2000), humans prefer places which offer both prospect (open 
view) and refuge (protection). Places that offer both prospect and protection help individuals and groups to observe potential animate hazards (offenders), to react and defend from potential dangers, as well as to find a protective space to keep oneself from being harmed. In this way, humans do not have to experience an area to determine its suitability. They could evaluate their surroundings and assume the amount of prospect and refuge afforded to decide whether it forms a suitable location. This theory became a basis for many research studies and theoretical models to explore the relationship between environmental clues and the fear of crime.

Fisher and Nasar (1992) applied and further developed Appleton's prospect and refuge theory to explain the effect of specific features in the built environment and the feeling of safety by researching campus students at Ohio University. They used prospect for the victim and refuge for the offender as a framework for understanding how different exterior design features affect perception of safety. Using Appleton's concepts, Fisher and Nasar (1992) developed a general typology for evaluating individuals' perception based on the amount of prospect and refuge afforded within the surrounding environment. Figure one shows this typology.

The cell entries in Figure 1 show victims' perceptions of safety. Fisher \& Nasar argued that areas characterised by large amounts of refuge and minimal prospect would evoke the highest degree of fear amongst individuals. These areas are known as 'blind spots'. Large amounts of refuge means large numbers of hiding places for potential offenders. Nasar and Fisher's model predicts that the highest degree of safety would be displayed in areas identified by minimal refuge for potential offenders and high prospect for victims. They argue that, if the surrounding area affords the victim a high degree of visibility/permeability and minimal hiding places for offenders, then the victim could evaluate the area and avoid the attack or opportunistic crime.
Victim Prospect

\begin{tabular}{ll|l|l|} 
& $\begin{array}{l}\text { High Open } \\
\text { Prospect }\end{array}$ & $\begin{array}{l}\text { Low Blocked } \\
\text { Prospect }\end{array}$ \\
\hline & $\begin{array}{l}\text { Low } \\
\text { (No hiding } \\
\text { places) }\end{array}$ & Most Safe & $\begin{array}{l}\text { Moderately } \\
\text { Safe }\end{array}$ \\
\hline $\begin{array}{l}\text { High } \\
\text { (Many hiding } \\
\text { places) }\end{array}$ & $\begin{array}{l}\text { Moderately } \\
\text { Unsafe }\end{array}$ & Most Unsafe \\
\hline
\end{tabular}

Figure 1: Typology of Perception of Safety (Fisher \& Nasar, 1992, p 61)

Apart from refuge and prospect, Fisher and Nasar argue that individuals' feelings of safety are influenced by the degree to which a space affords an opportunity for escape. They found that when possibilities for escape were low, fear of crime was higher (Fisher \& Nasar, 1992). Escape may provide either an exit route from a potential threat or a connection to others who could respond in case of an attack. Prospect and easy escape may go hand-inhand as spaces which limit prospect may also cut off possibilities for escape. However, they would differ in some situations. For example, a long road across a lake may have high prospect and no refuge but limited options for escape.

In this context, prospect, refuge, and escape are relevant features in relation to fear of crime. Prospect and refuge theory and Fisher and Nasar's fear of crime model predict that perceived safety would improve with increases in prospect and escape for the victim and decreases in refuge for the offender.

\section{Socio-Cultural Approaches}

Some researches argue that fear of crime in the public realm is influenced by sociocultural, demographic variables (Blobaum \& Hunecke, 2005; Byrne \& Wolch, 2009; Garafalo, 1981). Feelings of fear of crime may be dependent on individuals' sex. Many researchers confirm that females feel significantly less safe than males when they walk at night time (Australian Bureau of Statistics, 2010; Fisher \& Nasar, 1992; Kelly, 1986; Yavuz \& Welch, 2010). This may result in females behaving differently in space at different times of the day. For example one of the reasons Asian women are under- 
represented in urban parks at night is due to fear of crimes (Cranz, 1982). As Hunecke and Blobaum (2005) noted, males and females sense of danger in public space is associated with different kind of incidents. Although males anticipate a fight, females will mainly fear rape or sexual assault when walking alone a park after dark. If they go to a park after dark, they will usually go there as a group, with friends or with family members (Blobaum \& Hunecke, 2005) .

Although many explanations exist in explaining women's low level of perceived safety in public areas such as parks, the most contemporary explanations of women's fear centres on gender differences in socialisation in which women are socialised to be more passive and dependent (Garafalo, 1981; Kelly, 1986; Lagrange, Ferraro, \& Supancic, 1992; Lee \& Farrall, 2009). However, some argue that explanations of women's fear in public spaces extend beyond socialisation arguments and need to demonstrate the importance of environment and experiential factors (MacMillan, Nierobisz, \& Welsh, 2000). For example, many studies demonstrate the impact on women's safety due to experiences with stranger sexual harassment in public and semipublic environments (Gardner, 1995; MacMillan et al., 2000).

Many studies show that both women and elders are two similar social groups in terms of fear of crime and therefore they can be considered as two predictors of fear of crime which are linked to vulnerability (Hale, 1996). Usually older persons and women have highest fear of crime (Australian Bureau of Statistics, 2010). However, in reality both these social groups have lower victimisation rates in public space. As elsewhere stated women often experience violence in the home. The reasons why women and older persons have high fear of crime in public space may be due to perception of sexual harassments, less control over potentially threatening, stressful, and dangerous situations due to their physical strength. The lower victimisation rates in older persons and women could be a consequence of fear of crime as more vulnerable persons are more conscious about crimes and take extra precautions against victimisation (Hale, 1996). For example they may be more vigilant by avoiding walking at night, ensuring they walk with friends, and carefully observing the environment, expecting a crime particularly when walking at night. Despite the fact that elderliness is associated with fear of crime, some studies show that it was not a powerful attribute in predicting fear of crime and compared with sex it was insignificant (Blobaum \& Hunecke, 2005; Mawby, 2004)

There has also been a considerable amount of research examined about race as an explanatory factor in fear of crime. However, evidence of past research indicates mixed findings. Some research has revealed that nonwhites felt less safe than whites (Fisher \& Sloan, 1995; Lagrange et al., 1992). A study done in Sydney and Melbourne revealed that visible minorities such as Arabs, Asian, and Jewish communities have a special fear of racist violence (Human Rights and Equal Opportunity Commission, 1991). Similarly, when many races/ethnicities were examined in America, whites were more likely to be safer than Blacks and Hispanics (Kareem L \& Gabbidon, 2010).

One main explanation provided to understand this correlation connects to the impoverished physical condition of their living environment. Studies have found that a disproportionate number of minorities live in impoverished communities (Davis, 2006; Kareem L \& Gabbidon, 2010; Massey \& Denton, 1993; Wilson, 1987). The conditions in such physical environments (e.g., graffiti, incivilities, dilapidated buildings, etc.) tend to signify a risk of victimisation among inhabitants. In contrast to the argument that non-whites feel more fear, some studies have found that whites felt more unsafe than nonwhites in public settings (Rountree \& Land, 1996). Rountree and Land's (1996) study on the effect of racial competition and minority status on fear of crime for black and white respondents in a white dominant area in the USA, show that the racial minority of blacks felt less fear of crime compared to whites.

Evans, Fraser and Walklate (1996) findings can be useful to explain the logic for this situation that concerns the level of social integration in a particular community. They concluded that a community may live in a 
physically disordered settlement, but if people trust each other it will feel safer than people who do not have others who they trust living around them. Another explanation for this involves the way minorities are constructed within the newspaper in discourses of criminality (Tulloch et al., 1998). When blacks or Aboriginal youths' faces are depicted as criminal faces, many white people accept this image of minority groups as criminals and then encountering them in public spaces evokes greater fear of being a crime victim.

The media representations of crime and its effect on fear of crime have been further discussed in fear of crime literature. Some argue that the media is one of the various stimuli that create 'geographies of fear' and affect people's use of public and private space (Pain \& Shirlow, 2003; Valentine, 1992). The key argument forwarded was that media, dominated by television and newspapers, generates irrational fear through crime news and over-emphasis on crime threats. Television news primarily is seen as distorting the reality of crime issues. However, some have criticised this relationship between fear of crime and media. They argue that the conceived relationship is due to assumptions about the audience who are seen as passive recipients of ideological messages who do not scrutinise what they view (Lupton \& Tulloch, 1999). A study of perception of fear among middle class families in Kent in the United Kingdom found no substantive correlation between fear of crime in the neighbourhood and exposure to crime on television (Banks, 2005). Others have found that television crime may stimulate a fear of other places (cities) from which the viewer is physically distant (Coleman, 1993). On the whole, the effect of media on perceived fear tends to be inconclusive, and media representations of crime may not alone make a considerable impact on perceived safety and people's behaviour in urban and rural settings. In fact, other socio-cultural variables such as social assistance and real experiences have a profound effect on individuals' fear of crime discourse.

In this regard, Sundeem (1984) found that international university students' fear of crime was strongly correlated to number of months in U.S. The significance of this study in relation to fear of crime studies and Garofalo's model is that perception of one's neighbourhood environment and its dangerousness, as well as the assurance of assistance will be gained if required from the environment, continued to be important factors alone with other variables, such as age, gender, and living situation. This approach permits some comparability with other studies as it has been widely used and cited in similar studies to explain feeling of safety in public areas.

\section{Presence of People and Fear of Crime}

Individuals' fear of crime in public areas can be influenced by presence of other people. Goffman (1971) proposed that individuals constantly look for other social clues in the surrounding area when they are in threatening situations. For example, individuals can come across potentially reputable and disreputable people in urban settings. Disreputable people or dangerous-looking people can be a social incivility and thus evoke fear of crime (Lagrange et al., 1992) On the other hand, presence of reputable people can give a confidence to persons who use spaces particularly at night (Nasar \& Jones,1997). Although many studies have focused on how fear of crime is related to potentially threatening individuals, not many studies researched how presence of others raises the sense of safety. In this regard, Warr (1990)and Whyte (1980) findings about urban parks and public spaces show that presence of people can encourage safe feelings or use. Whyte (1980) suggested that when people see other people who engage in expected and acceptable use (mutually acceptable use), they serve as a social clue or signify as a safe clue for others to use the spaces. In the same way, Nasar \& John (1997) observed that students felt fearful in the absence of people when walking at night in a campus setting.

This indicates that although it has not been extensively researched, the handful of past studies suggest presence of appropriate others reassures the setting and gives people extra confidence to use the space. However, most of the studies that researched presence of people as a positive environmental clue focused on 
experimentally manipulated situations (Warr, 1990) (for an exception, see Nasar \& John, 1997). At the same time, such past studies have often focused on the effect of the presence of people as an environmental clue alone that lower or increase the fear.

\section{Merging Fear of Crime with Environmental Clues Social Variables}

As stated above and overall, most of the past researches on fear of crime have focused either environmental variables (graffiti, dilapidated buildings, light, enclosures, hiding places, and disorderly areas) or social variables (gender, race, media, age, and presence of people) separately. However, in recent years, a few studies attempted to study whether the combination of environmental and social variables create low or high fear environments (Jorgensen, Ellis, \& Ruddell, 2012; Nasar \& Jones, 1997). The next section will discuss some limitations of Appleton's prospect and refuge theory and subsequent model developed by Nasar \& Jones, and then it will identify ways to expand this model by incorporating a combination of environmental cues and social variables to study fear of crime

Appleton's theory of prospect and refuge and Nazar and Fisher's model provide strong evidence that there is a relationship between fear of crime and built environmental features. However, this theory has been criticized in many aspects. Appleton defined refuge as fixed elements in the environment that provide hiding features. Refuge can also be linked to non-fixed elements in the built environment. For example, humans can be a refuge. As discussed earlier, presence of humans when one walks along at night can increase or decrease a sense safety. A place in which nonthreatening and potentially supportive people are present can offer a refuge for the victim. In previous studies (Newman, 1971) on fear of crime and environmental features, presence of humans was excluded and human access was controlled at the time that the research was conducted. However, in one study (Nasar \& Jones, 1997), fear of crime was correlated with prospect, hiding spaces and presence of humans as a refuge or a threatening element. They found places that were identified as having a high level of overview, a low level of hiding places and presence of groups people tended to be viewed as safer than places without people, low prospect and high level of hiding places. Similarly, a more recent study in a park setting showed that fear perception in parks is jointly influenced by environmental clues (concealment) and social variables : the presence of other people recreating in a park setting and the gender of individuals when recreating alone in a park setting (Jorgensen et al., 2012). However, little research has been conducted to validate the hypothesis that the presence of people influenced sense of safety and therefore further research is needed to support this argument. Nasar and Jones (1997) call for further studies to confirm the relationship between fear of crime, presence of people, level of overview and hiding spaces.

In the previous studies, the relationships between fear of crime and prospect and refuge theory and social variables has been tested more on experimentally manipulated social and physical settings or campus settings than other settings (Blobaum \& Hunecke, 2005; Nasar et al., 1993). In some instances, such studies have been based on photographic representations of sites for respondents. (Blobaum \& Hunecke, 2005; Fisher \& Nasar, 1992; Loewen, Steel, \& Suedfeld, 1993; Nasar et al., 1993). However, crime incidents occur in live and more interactive areas in the built environment and thus fear of crime is experienced in other settings such as city centres, parks and neighbourhood areas at night. In fact, researchers have begun to move away from photographic representation sites or manipulated sites to more interactive real life sites. Such studies suggest phenomenological research or real situations are required to assess validity of combined variables: prospects, refuge, and social clues.

When considering past research on fear of crime in public space in Australia, most studies tended to concentrate on Metropolitan areas (Collins, 2005; Nyland, Forbes-Mewett, \& Marginson, 2010) ; Western \& Stimson, 2005). Less frequently, researchers studied fear of crime in regional settings. At the same time, we know little about how social groups with different ethnic backgrounds such as international students experience the built environmental features in terms of prospect 
and refuge theory. It is believed that a regional city context provides a unique contribution to exiting research about the international Asian university students' experience of fear of crime in relation to environmental clues. An important aspect of that nature of research will be to merge socio-cultural theory and prospect theory.

\section{Conclusion}

In the past many studies focused on occurrence of crime and its relationship to built environment. As has been previously discussed, fear of crime affects human behaviour in many ways. The previous studies on fear of crime have mainly focused on influence of social cultural variables on fear of crime in spatial contexts. There is certainly a level of inter-individual variance in evaluative responses to physical attributes of environments but socio-cultural theory alone tells little about site specific characteristics and fear of crime. Conversely, there seem to be places that evoke higher levels of fear than others do.
However, prospect and refuge theory has been applied to test fear of crime and physical features in urban settings. This theory has been tested mainly in campus settings in North America. It has not been tested in other lived environments such as city centres and residential neighbourhood settings to test the validity of the theory. It is also needed to extend this theory to test influence of presence of people on fear of crime as another feature in the urban setting. It is also important to study this hypothesis with different social groups such international Asian university students to examine applicability of the theory. In doing so, it will extend the current work on prospect and refuge in relation to subjective interpretation of environment safety as their influenced by different cultural backgrounds. At last it needs to stress that urban planning needs a holistic approach to study fear of crime in cities which will merge prospect and refuge theory and socio-cultural theory.

\section{References}

Andrews, M., \& Gatersleben, B. (2010). Variations in Perception of Danger, Fear and Preference in a Simulated Natural Environment Journal of Environmetal Psychology, 30, 473-481.

Australian Bureau of Statistics. (2010). Australian Social Trends: September 2010 (cat. no. 4102.0). Canberra, Australia.

Australian Education International, E. a. W. R. Department of Education. (2009). International Student Enrolment Data. Canberra: Australian Government. Retrieved from http://aei.gov.au/AEI/MIP/Statistics/

Banks, M. (2005). Spaces of Insecurity: Media and Fear of Crime in a Local Context. Crime Media Culture 1 (169), 169 -186.

Blobaum, A., \& Hunecke, M. (2005). Perceived Danger in Public Space:The Impacts of Physical Features and Personal Factors. Envionment and Behavior, 37(4), 465 - 486.

Borooah, V. K., \& Carcach, C. A. (1997). Crime and Fear: Evidence from Australia. The British Journal of Criminology, 37(4), 635-627.

Byrne, J., \& Wolch, J. (2009, 13 March). Nature, Race, and Parks: Past Research and Future Directions for Geographic Research. Progress in Human Geography, 33(6), 743-765.

Carmona, M., \& Tiesdell, S. (Eds.). (2007). Urban Design Reader. Oxford: Architectural Press. 
Coleman, C. (1993). The Influence of Mass Media and Interpersonal Communication on Societal and Personal Risk Judgements. Communication Research, 20(4), 611-628.

Collins, J. (2005). Ethnic Minorities and Crime in Australia: Moral Panic or Meaningful Policy Responces. Western Australia.

Cranz, G. (1982). Politics of Park Design. Cambridge: MIT press.

Crenshaw, E., \& John, C. S. (1989). The Organisationally Dependent Community: A Comparative Study of Neighbourhood Attachement. Urban Affairs, 24, 608-619.

Crowe, T. (2000). Crime Prevention Through Environmental Design (2 ${ }^{\text {nd }}$ ed.). Boston Butterworth: Heinman.

Davis, M. (2006). Planet of Slums. London: Verso.

Doran, B. J., \& Lees, B. G. (2005). Investigating the Spatio-temporal Links Between Disorder, Crime, and Fear of Crime. The Professional Geographer, 57(1), 1-12.

Evans, K., Fraser, P., \& Walklate, S. (1996). Whom can You Trust. The Politics of 'Grassing' on an Inner City Housing Estate. Sociological Review, 44(3), 359-380.

Ferraro, K. F. (1995, p.4). Fear of Crime: Interpreting Victimization Risk (pp. 4). New York: State University of New York Press.

Fisher, B., \& Nasar, J. L. (1992). Fear of Crime in relation to Three Exterior Site Features: Prospect, Refuge and Escape. Environment and Behavior, 24(January), 35- 65.

Fisher, B., \& Sloan, J. J. (Eds.). (1995). Campus Crime. Springfield IL: Charles C Thomas.

Gabriel, U., \& Greve, W. (2003). The Psychology of Fear of Crime. Conceptual and Methodological Perspectives. The British Journal of Criminology, 43(3), 600-614.

Gans, H. (1962). The Urban Villages :Group and Class in the Life of Italian Americans. New York: The Free Press.

Garafalo, J. (1981). The Fear of Crime:Causes and Consequences The Journal of Crimal Law and Criminology, 72(1981), 839 - 857.

Gardner, C. B. (1995). Passing by: Gender and Public Harassments. Berkeley: University of California Press.

Gottdiener, M. (2010). The New Urban Sociology (4 ed.). New York: Westview Press.

Human Rights and Equal Opportunity Commission. (1991). Racist Violence: Report of the National Inquiry into Racist Violence in Australia. Canberra: Australian Government Publishing Service.

Hunter, A. (1975). The Loss of Community: An Empirical Test Through replication. Americal Sociological Review, 40, 537- 552.

Jackson, J., Farrall, S., \& Emily, G. (2007). Theorising the Fear of Crime: The Cultural and Social Significance of Insecurities about Crime. Retrieved from http://papers.ssrn.com/sol3/papers.cfm?abstract_id=1012393 
Jacobs, J. (1961). The Death and Life of Great American Cities. New York: Vintage.

Jeffery, R. (1971). Crime Prevention Through Environmental Design. Beverly Hills: Sage Publications.

Jorgensen, L. (2007). Crime Prevention through Environmental Design. Crime Prevention Through Environmental Design, 63(3), 26-32.

Jorgensen, L., Ellis, G. D., \& Ruddell, E. (2012). Fear Perceptions in Public Parks: Interactions of Environmental Concealment, the Presence of People, and Gender. Environment and Behaviour, xx(x). doi:10.1177/00139165124466334

Kareem L, \& Gabbidon, S. L. (2010). Race Ethnicity and Perception of Safety Among a National Sample of Americans. Criminal Justice Review 35(281).

Kelly, E. (1986). What Makes Women Safe? Housing Review, 35(6).

Koskela, H., \& Pain, R. (2000). Revisiting Fear and Place:Women's Fear of Attack and the Built Environment. Geoforum, 31, 269-280.

Lagrange, R. L., Ferraro, K. F., \& Supancic, M. (1992). Perceived Risk and Fear of Crime: Role of Social and Physical Incivilities. Crime and Delinquency 29(3), 311-344.

Lee, M., \& Farrall, S. (Eds.). (2009). Fear of Crime. Ney York: Routledge

Loewen, L., Steel, G. D., \& Suedfeld, P. (1993). Perceived Safety from Crime in the Urban Environment. Envionmental Psychology, 13, 323-331.

Loukaitou-Sideris, A. (1999). Hot Spots of Bus Stop Crime:The Importance of Enviornmetal Attributes. Journal of American Planning Association, 65(4), 395- 411.

Loukaitou, A., \& Eck, J. E. (2007). Crime Prevention and Active Living. Americal Jounal of Health Promotion 21(4), 380-389.

Lupton, D., \& Tulloch, J. (1999). Theorising Fear of Crime: Beyond the Rational/irrational Opposition. British Journal of Sociology, 50(3), 507-523.

MacMillan, R., Nierobisz, A., \& Welsh, S. (2000). Experiencing the Streets: Harassment and Perceptions of Safety among Women. Journal of Research in Crime and Delinquency 37, 306-322.

Maltz, M., Gordon, A., \& Friedman, W. (1990). Mapping Crime in Its Community Setting: Event Geography Analysis. New York: Springer-Verlag.

Marusic, B. G. (2010). Successful Public Spaces. Annales-Anali Za Istrske in Mediteranske Studije-Series Historia Et Sociologia, 20(1), 103-118.

Massey, D. S., \& Denton, N. A. (1993). American Apartheid. Cambridge: Harvard University Press.

Mawby, R. (2004). Reducing Burglary and Fear among Older People: An Evaluation of a help the Aged and Homesafe Initiative in Plymouth. Social Policy and Administration, 38(01), 120. 
Nasar, J. L., Fisher, B., \& Grannis, M. (1993). Proximate Physical Cues to Fear of Crime. Landscape and Urban Planning, 26, 161-178.

Nasar, J. L., \& Jones, K. M. (1997). Landscape of Fear and Stress,1997, 29,3,291. Envionment and Behaviour, 29(3), 291-323.

Newman, O. (1971). Architectural Defence for Crime Prevention. Washington D.C.: National Institute for Law Enforcement and Criminal Justice.

Newman, O. (1972). Defencible Space. New York: The Macmillan Company

Newman, O. (1996). Creating Defensible Space. New York: U. S. Department of Housing and Urban Development.

Nyland, C., Forbes-Mewett, H., \& Marginson, S. (2010). "The International Student Safety Debate: Moving Beyond Denial. Higher Education Research and Development, 29(1), 89-101.

Pain, R., \& Shirlow, P. (2003). The 'geographies and politics of fear'. capital and Class, 80, 1526.

Petherick, N. (2000). Envionmental Design and Fear. Western Geography, 10(11), 89-112.

Planning Institute of Australia. (2010). Accreditation Policy for the Recognition of Australian Planning Qualifications for the Urban and Regional Planning. Planning Institute of Australia.

Poyner, B. (1983). Design against Crime. London: Butterworths.

Rountree, P. W., \& Land, K. C. (1996). Perceived Risk versus Fear of Crime:Empirical Evidence of Fear of Conceptually Distinct Reactions in Survey Data, Social Forces, 74, 1353-1376.

Samson, R., \& Raudenbush, S. W. (1999). Systematic Social Observation of Public Spaces : A New Look at Disorder in Urban Neighbourhoods. Americal Jounal of Sociology 105(3), 603-651.

Shaftoe, H. (2008). Convivial Urban Spaces. London: Earthscan Publishers.

Skogan, W. (1990). Disorder and Decline: Crime and the Spiral of Decay in American Neighbourhoods. Los Angeles: University of California Press.

Sundeem, R. A. (1984). Explaing the Fear of Crime among International Students from Developing Countries: A Revised Model. Criminal Justice Review, 9(7), 7-13.

Talen, E. (1996). Sense of Community and Neighbourhood Form: An Assessment of the Social Doctrine of New Urbanism. Urban Studies, 36, 1361-1379.

Tulloch, J., Lupton, D., Blood, W., Tulloch, M., Jennett, C., \& Enders, M., T. c. r. council. (1998). Fear of Crime : Audit of Literature and Commuinity Programs. Canberra: Common Wealth Australia.

UN-HABITAT. (1996). Safer Cities. Nairobi. 
Valentine, G. (1992). Images of Danger:Women's Source of Information about Spatial Distribution of Male Violence. Area, 24(1), 22-29.

Warr, M. (1990). Dangerous Situations: Social Context and Fear of Victimization. Social Forces, 68(3), 891-907.

Whyte, W. H. (1980). The Social Life of Small Urban Spaces. New York, NY: Project for Public Spaces.

Wilson, J., \& Kelling, G. L. (1982). The Police and Neighbourhood Safety: Broken Windows Theory. The Alantic Monthly, 29-38.

Wilson, W. J. (1987). The Truly Disadvantaged. Chicago: University of Chicago Press.

Yavuz, N., \& Welch, E. W. (2010). Addressing Fear of Crime in Public Space: Gender Differences in Reaction to Safety Measures in Train Transit. Urban Studies 47(12), 24912512. 